\title{
Nuclear patterns of human breast cancer cells during apoptosis: characterisation by fractal dimension and co-occurrence matrix statistics
}

Received: 12 February 2005 / Accepted: 23 May 2005 / Published online: 30 July 2005

(C) Springer-Verlag 2005

\begin{abstract}
An analytical strategy combining fractal geometry and grey-level co-occurrence matrix (GLCM) statistics was devised to investigate ultrastructural changes in oestrogen-insensitive SK-BR3 human breast cancer cells undergoing apoptosis in vitro. Apoptosis was induced by $1 \mu \mathrm{M}$ calcimycin (A23187 $\mathrm{Ca}^{2+}$ ionophore) and assessed by measuring conventional cellular parameters during the culture period. SK-BR3 cells entered the early stage of apoptosis within $24 \mathrm{~h}$ of treatment with calcimycin, which induced detectable changes in nuclear components, as documented by increased values of most GLCM parameters and by the general reduction of the fractal dimensions. In these affected cells, morphonuclear traits were accompanied by the reduction of distinct gangliosides and loss of unidentifiable glycolipid molecules at the cell surface. All these changes were shown to be involved in apoptosis before the detection of conventional markers, which were only measurable during the active phases of apoptotic cell death. In overtly apoptotic cells treated with $1 \mu \mathrm{M}$ calcimycin for $72 \mathrm{~h}$, most nuclear components underwent dramatic ultrastructural changes, including marginalisation and condensation of chromatin, as reflected in a significant reduction of their fractal dimensions. Hence, both fractal
\end{abstract}

This work was supported by grant 31-57626.99 from the Swiss National Science Foundation and grant FOR 450.94 from the Swiss Cancer League.

G. A. Losa $(\bowtie) \cdot$ C. Castelli

Institute for Scientific Interdisciplinary Studies,

Via F. Rusca 1

P.O. Box 1132, 6600 Locarno, Switzerland

e-mail: glosa@cerfim.ch

Tel.: +41-91-7516424

Fax: $+41-91-7516424$

G. A. Losa

Faculty of Biology and Medicine, University of Lausanne, 1015 Lausanne, Switzerland

Present address:

C. Castelli

OCL Hospital,

6900 Lugano, Switzerland and GLCM analyses confirm that the morphological reorganisation of nuclei, attributable to a loss of structural complexity, occurs early in apoptosis.

Keywords Early/late apoptosis - Nuclear eu-/heterochromatin - Fractal dimension - Grey-level co-occurrence matrix (GLCM) analysis · Surface gangliosides ·

Human breast cancer cells

Abbreviations FD: fractal dimension - GLCM: grey-level co-occurrence matrix · FITC: fluorescein isothiocyanate $\cdot$ PI: propidium iodide $\cdot$ TLE: total lipid extract - NM: perinuclear membrane - NMBHC: nuclear membrane-bound heterochromatin space and outline . SHC: scattered heterochromatin space and outline $\cdot \mathrm{HC}$ : total heterochromatin space and outline - IC: inter(eu) chromatin space and outline $\cdot$ Tdt: Terminal deoxynucleotidyl Transferase

\section{Introduction}

The process of apoptosis is a physiological form of cell death that occurs in all tissues. Those cells that are committed to die undergo a series of characteristic functional and morphological changes that are mostly irreversible (Kerr et al. 1972, 1994; Wyllie et al. 1980; Raff 1998; Schwartzman and Cidlowski 1993). Apoptosis occurs rarely in living tissues and is difficult to recognise, because it takes place rapidly in vivo and is a natural residual process (Savill 1997; Losa and Graber 1998; Ferguson and Anderson 1981). Unfortunately, the methods currently available do not adequately identify the early phases of apoptosis when the cells appear overtly normal and healthy. In experimentally induced apoptosis of epithelial and other non-lymphoid cells, fine ultrastructural changes may occur in nuclear chromatin components and nuclear membranes at the beginning of apoptosis. Such changes could be evaluated by using unconventional methods of morphometry, based on fractal geometry (Mandelbrot 1983; Losa and Nonnenmacher 1996; Nonnenmacher et al. 
1994), which allows the measurement of the majority of irregular and wrinkled cellular components by a single descriptive parameter, the fractal dimension (FD). Several reports have documented the use of fractal morphometry for describing irregular morphological traits and changes in the ultrastructural features of membrane organelles, including chromatin and other nuclear components in various types of healthy, diseased and/or tumour cells (Baish and Jain 2000; Cross 1994; Paumgartner et al. 1981; Landini and Rippin 1993; Sepulcre et al. 1998). Fractal morphometry has been employed to analyse electronmicroscopic (EM) images and to characterise nuclear euchromatin and heterochromatin domains (Chan 1995; Marinelli et al. 1998) of lymphoid cells (Maraldi et al. 1998), normal and malignant liver cell nuclei (Nielsen et al. 1999), lymphocytic nuclear membranes in Mycosis fungoides and chronic dermatitis (Bianciardi et al. 2002) and pericellular membranes of healthy immune competent lymphocytes and human leukemic cells (Losa et al. 1992). Recently, the fractal method was employed to document the feasibility of using ultrastructural changes in cell surface and nuclear inter(eu)chromatin to assess the early phases of apoptosis in human breast cancer cells prior to changes in conventional cell markers (Castelli and Losa 2001). Methods based on grey-level density discrimination have been applied to histological sections to measure the FD of the chromatin texture of nuclei in normal and malignant cells (Landini and Rippin 1996; Irinopoulou et al. 1993; MacAulay and Palcic 1990; Doudkine et al. 1995; Einstein et al. 1998; Wehn et al. 1999). Grey-level cooccurrence matrix (GLCM) statistics have been used to estimate image textural features of nuclei and other cell organelles from EM preparations (Chan 1995; Rigaut 1987). Obviously, these ultrastructural changes might reflect a variety of peculiar morphological traits and metabolic pathways. However, neither fractal morphometry nor GLCM studies have been carried out on EM preparations of nonlymphoid human cancer cells undergoing apoptosis. The present studies aim at evaluating, by fractal geometry and statistical analysis, the ultrastructural changes in nuclei of oestrogen-insensitive SK-BR3 human breast cancer cells, at the beginning and during the active phases of apoptosis induced in vitro by calcimycin, a $\mathrm{Ca}^{2+}$ ionophore (Squier and Cohen 1997; Gwag et al. 1999), and at correlating these changes with the occurrence of cellular markers and surface sialosphingolipids.

\section{Materials and methods}

\section{Reagents}

IMDM medium, gentamycin and fetal calf serum (FCS) were obtained from Seromed (Oxoid, Basel, Switzerland). DME/F-12 w/o phenol red was obtained from Sigma (Buchs, Switzerland). Calcimycin (A23187) was purchased from Calbiochem (Juro Supply, Lucerne, Switzerland), annexin-V-fluorescein isothiocynate (FITC) from
Nexins Research (Hoeven, The Netherlands), terminal deoxynucleotidyl transferase (TdT) and fluorescein-11-dUTP from Amersham (Dübendorf, Switzerland). Standard $\mathrm{GM}_{1}$ and $\mathrm{GM}_{3}$ gangliosides were obtained from Matreya (Basel, Switzerland) and $\mathrm{GD}_{1 \mathrm{a}}$ and $\mathrm{GT}_{1 \mathrm{~b}}$ from Fidia Research Laboratories (Abano, Italy). All other chemicals and reagents of the finest grade of purity were purchased from Sigma and Fluka (Buchs, Switzerland), whereas organic solvents and $10 \times 10 \mathrm{~cm}$ Silica gel 60 high-performance thin-layer chromatography (HPTLC) plates were purchased from Merck (Dietikon, Switzerland).

\section{Cell cultures}

Oestrogen-insensitive SK-BR-3 human mammary cancer cells were cultured in flasks in IMDM supplemented with $2 \mathrm{mM}$ L-glutamine, $10 \%$ heat-inactivated FCS and $10 \mu \mathrm{g} /$ $\mathrm{ml}$ gentamycin at $37^{\circ} \mathrm{C}$ in a humid $5 \% \mathrm{CO}_{2}$ atmosphere. Cells $\left(10^{5}\right.$ cells $/ \mathrm{ml}$ or $2 \times 10^{4}$ cells $\left./ \mathrm{cm}^{2}\right)$ were cultured for $48 \mathrm{~h}$ in DME/F-12 medium without phenol red supplemented with 5\% heat-inactivated FCS prior to experiments. The medium was removed and the cells were rinsed with $\mathrm{DME} / \mathrm{F}-12$. They were then incubated in DME/F-12 supplemented with $5 \%$ heat-inactivated FCS containing $1 \mu \mathrm{M}$ calcimycin (inducer of experimental apoptosis) in dimethylsuphoxide (DMSO), whereas control cells were grown in medium plus an equivalent final concentration of DMSO $(0.1 \%)$.

Treated and control cells were harvested by mild trypsinisation and rinsed. Viability was assessed by trypan blue exclusion. Cells were counted in a Neubauer chamber.

\section{Cellular characterisation of apoptosis}

Four different conventional methods were applied for measuring apoptosis in SK-BR-3 cells, namely intermediate permeability to propidium iodide (PI) and annexin- $\mathrm{V}$ as membrane events and TUNEL and sub- $\mathrm{G}_{0} / \mathrm{G}_{1}$ peak pertaining to nuclear chromatin.

\section{Membrane permeability assay}

The change in the permeability of the plasma membrane to PI was used to differentiate living from apoptotic and dead cells (Graber and Losa 1995; Ormerod et al. 1992). SKBR-3 cells $\left(5 \times 10^{5}\right)$ were washed in $0.9 \% \mathrm{NaCl}(\mathrm{pH} 7.4)$, suspended in $5 \mu \mathrm{g} / \mathrm{ml}$ PI in $0.9 \% \mathrm{NaCl}$, incubated for $7 \mathrm{~min}$ in the dark at room temperature, centrifuged and suspended in $0.9 \% \mathrm{NaCl}$. PI uptake was analysed in a FACScan (Becton and Dickinson, Basel, Switzerland) equipped with CELLQuest software. Three distinct populations of living, apoptotic and dead cells corresponding to cells with low, intermediate and high levels of permeability to PI were displayed in a two-parameter dot plot, i.e. PI fluorescence (FL-2H) versus cell dimension (FSC). 
Annexin-V labelling

Annexin- $\mathrm{V}$ is an adhesion molecule that binds tightly to the phosphatidylserine on the outer leaflet of the plasma membrane in the presence of $\mathrm{Ca}^{2+}$. SK-BR-3 cells $\left(2 \times 10^{5}\right)$ were washed with cold $0.9 \% \mathrm{NaCl}$ and incubated for $15 \mathrm{~min}$ at room temperature with $\mathrm{Ca}^{2+}$-binding buffer containing annexin-V-FITC (diluted 10-fold) and $1 \mu \mathrm{g} / \mathrm{ml} \mathrm{PI}$ (Vermes et al. 1995). The stained cells were analysed for annexin-V-FITC in the fluorescence channel 1 (FL-1H) and for PI in the FL-2H channel with a FACScan (Becton and Dickinson) equipped with CELLQuest software.

TdT-mediated dUTP nick end labelling assay

DNA strand breaks were labelled at $3^{\prime}-\mathrm{OH}$ ends with fluorescein-deoxynucleotide (dUTP) by exogenous TdT according to a slightly modified version of a published method (Gorczyca et al. 1993). SK-BR-3 cells (untreated or treated with calcimycin) were fixed in $0.5 \%$ formaldehyde in phosphate-buffered saline (PBS $\mathrm{pH} 7.4$ ) for $20 \mathrm{~min}$ at room temperature, rinsed with $\mathrm{PBS}$ and post-fixed with $70 \%$ ethanol for $24 \mathrm{~h}$ at $-20^{\circ} \mathrm{C}$. Following fixation, the cells were rinsed twice with PBS containing $0.5 \%$ bovine serum albumin and $0.1 \%$ sodium azide. Cells $\left(10^{6}\right)$ were resuspended in $50 \mu \mathrm{l}$ of a solution containing $100 \mathrm{mM}$ sodium cacodylate $(\mathrm{pH} 7.2), 2 \mathrm{mM} \mathrm{CoCl}_{2}, 0.5 \mathrm{mM}$ mercaptoethanol, 0.5 nmoles FITC-labelled dUTP and $10 \mathrm{U}$ $\mathrm{TdT}$ and incubated in the dark for $30 \mathrm{~min}$ at $37^{\circ} \mathrm{C}$. Finally, the cells were rinsed twice with $0.1 \%$ Triton $\mathrm{X}-100$ in PBS and then resuspended in PBS. Data were collected on a FACScan cytometer with a standard argon laser and a band-pass filter for FL1-H. Data analysis was performed with CELLQuest software. A control was carried out by omitting TdT.

Cell cycle and sub- $\mathrm{G}_{0} / \mathrm{G}_{1}$ peak

Cells $\left(10^{6}\right)$ were incubated at room temperature for $30 \mathrm{~min}$ in hypotonic $0.1 \%$ sodium citrate containing RNAse (5 U/ml), 0.1\%, Triton X-100 and $50 \mu \mathrm{g} / \mathrm{ml}$ PI (Graber and Losa 1995). The percentages of cells in each phase of the cell cycle were measured by flow cytometric analysis on a FACScan (Becton and Dickinson) equipped with CELLQuest software for acquisition and ModFit LT 2.0 (Verity Software House, Topsham, USA) for the evaluation of the cell cycle on a fluorescence- 2 channel/area (FL2A). Multiplets were discriminated by gating the events on a linear plot FL-2A versus fluorescence-2/width (FL$2 \mathrm{~W})$. Nuclei from human peripheral blood lymphocytes were used as an internal DNA standard. The sub-diploid $\mathrm{G}_{0} / \mathrm{G}_{1}$ area was determined by measuring cellular events on a log histogram on FL-2H according to an established method (Nicoletti et al. 1991).
Sphingolipids analysis

\section{Extraction of total lipids}

Total lipid extracts (TLE) were prepared from homogenates of $10^{7}$ SK-BR-3 cells by using the chloroform-methanol method (Müthing 1996). Membrane pellets obtained from cell homogenates centrifuged at 100,000 $\mathrm{g}$ were suspended in $1 \mathrm{ml}$ water. Methanol $(5 \mathrm{ml})$ was added followed by $5 \mathrm{ml}$ chloroform. The mixture was sonicated for $5 \mathrm{~min}$ in a bath sonicator and left to extract overnight at $4^{\circ} \mathrm{C}$. Samples were centrifuged $\left(750 \mathrm{~g}, 10 \mathrm{~min}, 4^{\circ} \mathrm{C}\right)$ to remove protein and particulate matter. The pellet was extracted with $10 \mathrm{ml}$ chloroform-methanol $(1: 1)$ and then with $10 \mathrm{ml}$ chloroform/methanol (2:1). The combined extracts were evaporated to dryness. The residues were dissolved in about $1 / 4$ volumes of chloroform/methanol (1:1) and left to stand overnight at $-20^{\circ} \mathrm{C}$. Insoluble material was removed by centrifugation $\left(750 \mathrm{~g}, 10 \mathrm{~min}, 4^{\circ} \mathrm{C}\right)$. The final clear lipid extract was evaporated to dryness and used to separate glycosphingolipids.

\section{Ganglioside and glycosphingolipid isolation}

Gangliosides and glycosphingolipids were isolated by the method of (Ladisch and Gillard 1985) as modified by (Wagener et al. 1996). The TLE was dispersed in diisopropyl ether and 1-butanol $(6 / 4(\mathrm{v} / \mathrm{v}))$, vortexed and sonicated. The resulting opalescent suspension was mixed with $17.5 \mathrm{mM} \mathrm{NaCl}$ (half the volume of organic solvent) and vortexed and sonicated for several minutes until the TLE was completely dissolved. The mixture was centrifuged $\left(750 \mathrm{~g}, 10 \mathrm{~min}, 4^{\circ} \mathrm{C}\right)$ and the upper organic phase containing neutral lipids and phospholipids was carefully removed with a Pasteur pipette. The lower aqueous phase containing the gangliosides, together with a small amount of emulsion at the interface was extracted with the original volume of organic solvent mixture and centrifuged again. A total of three extractions produced a clear thin-layer chromatography (TLC) pattern of the gangliosides. The clear to slight opalescent aqueous phase was lyophilised and dissolved in $2 \mathrm{ml}$ water-methanol (1:1) by sonication. Salts were removed by passage through a C8-plus cartridge (Waters, Switzerland; Wagener et al. 1996). The column was prepared according to the manufacturer's instructions. Samples were loaded, washed with $20 \mathrm{ml}$ water, concentrated in a stream of nitrogen and eluted with $3 \mathrm{ml}$ methanol and $6 \mathrm{ml}$ chloroform-methanol $(1: 1)$.

\section{TLC protocol}

The isolated glycosphingolipids were separated by TLC on $10 \times 10 \mathrm{~cm}$ HPTLC plates that had been activated by heating to $110^{\circ} \mathrm{C}$ for $45 \mathrm{~min}$. The plates were first eluted with 
Fig. 1 Electron micrographs of SK-BR-3 cells, untreated (a) and treated (b) with $1 \mu \mathrm{M}$ calcimycin for 24 h. $\times 10,580$ $(1 \mathrm{~cm}=0.94 \mu \mathrm{m})$
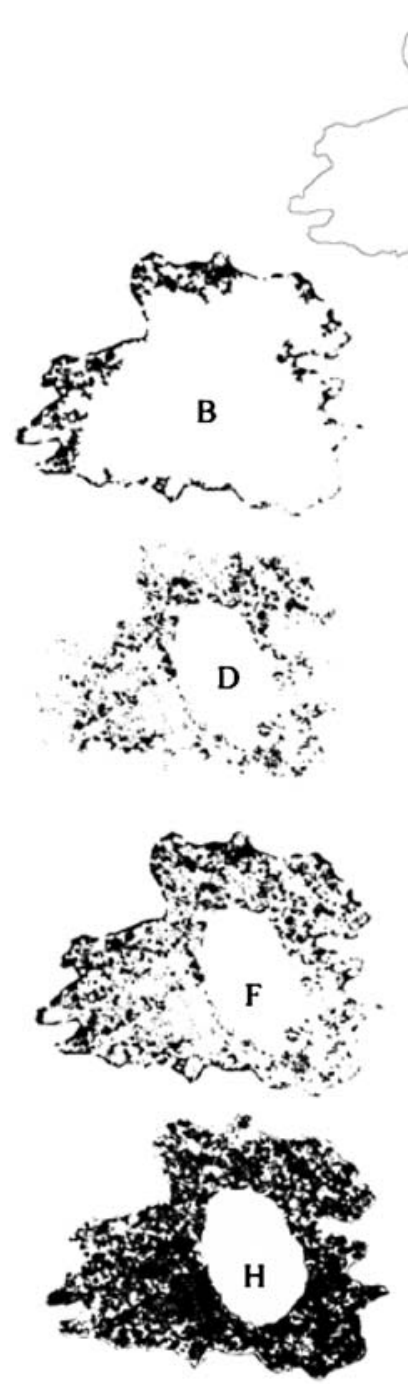

Fig. 2 Images of nuclear components segmented by grey-level threshold from electron micrographs of a calcimycin-treated nucleus (24 h). Nucleoli were interactively removed. a Perinuclear membrane. b, c Nuclear membrane-bound heterochromatin space and outline. d, e Scattered heterochromatin space and outline. f, g Total heterochromatin space and outline. h, i Inter(eu)chromatin space and outline. $\times 10,580$

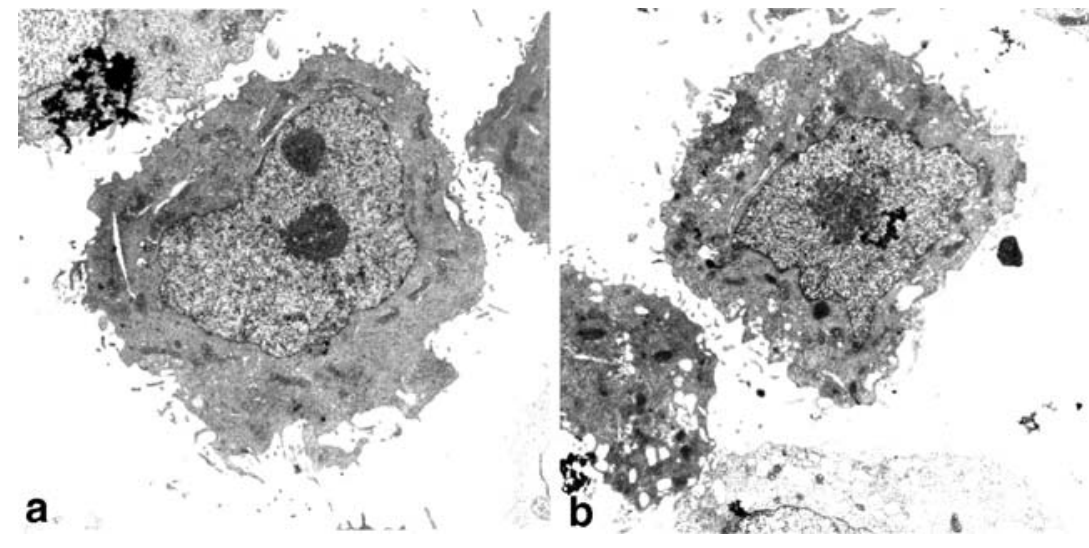

methanol to remove impurities. Concentrated glycosphingolipid samples were then applied with a $100-\mu$ l precision micro syringe (Hamilton, Bonaduz, Switzerland) mounted on a Linomat IV (Camag, Muttenz, Switzerland) and separated with a mixture of $\mathrm{CHCl}_{3}-\mathrm{MeOH}-0.25 \% \mathrm{CaCl}_{2}$ $(60: 40: 9)$

\section{Staining}

The TLC plates were dried and spots of lipids were revealed by spraying with a glacial acetic acid-sulphuric acid $\mathrm{H}_{2} \mathrm{SO}_{4}$-anysaldeyde 50:1:0.3 $\mathrm{v} / \mathrm{v}$ solution in a fume cupboard and by heating the plates at $120^{\circ} \mathrm{C}$ for $15 \mathrm{~min}$ in drying cabinet. Gangliosides appeared as green-brown spots. The ganglioside spots changed colour to brown after several hours in air, unlike oligosaccharides (green), cholesterol (blue) or phospholipids (pale-violet).

\section{Densitometry}

Glycosphingolipids were analysed quantitatively by densitometric scanning by using an Apple OneScanner (8 bit depth) and an NIH Image 1.59 program (developed at the US National Institutes of Health and available on the Internet at http://www.rsb.info.nih.gov./nih-image). Known amounts of individual gangliosides were used as standards and a calibration curve was established for each glycosphingolipid. The formula $\mathrm{OD}=\log _{10}(255 / 255$ grey level $)$, based on the Lambert-Beer law, allowed the conversion of the grey-level pixel values derived from single bands to a calibrated range (0-2.71 OD units) of optical density (OD) values. Glycosphingolipids from breast cancer cells were evaluated quantitatively from the correspondent peak area identified on HPTLC plates.

Mathematical tools and image analysis

\section{Transmission electron microscopy}

Cells $\left(1-5 \times 10^{6}\right)$ were fixed for $2 \mathrm{~h}$ at $4^{\circ} \mathrm{C}$ in $30 \mathrm{~g} / 1$ glutaraldehyde in $70 \mathrm{mg} / \mathrm{l}$ calcium chloride and $0.1 \mathrm{M}$ 
sodium cacodylate $\mathrm{pH} 7.4$, washed and post-fixed for $1 \mathrm{~h}$ at room temperature in $2 \mathrm{~g} / 100 \mathrm{ml}$ osmium tetraoxide in $0.1 \mathrm{M}$ sodium cacodylate adjusted to $340 \operatorname{mosm}$ with $\mathrm{NaCl}$ to reduce artefacts. They were dehydrated in an ethanol series $(70 \%-100 \%)$ and propylene oxide and embedded in Epon. Thin sections (interference colour: grey/silver) were cut on an LKB 2128 microtome, mounted on 200mesh grids coated with a Formvar film and stained with $5 \mathrm{~g} / 100 \mathrm{ml}$ uranyl acetate for $5 \mathrm{~min}$ and with lead citrate for $5 \mathrm{~min}$. Negative photomicrographs were taken on plastic plates (Kodak EM film 4489) with a Philips 400-ET microscope (magnification: $\times 4,600$ for single cells; Losa et al. 1992).

\section{Segmentation of cell components}

EM negatives of SK-BR-3 cells (untreated or treated with calcimycin) were printed (ILFORD, paper type 3 ) at a final magnification of $\times 10,580$, scanned by using a frame of 2,007 $\times 2,007$ pixels with an Apple OneScanner (300 dpi/ 8 bit depth, 256 grey levels) and stored as TIFF files on a Macintosh 8100/80 running Photoshop 2.5. Outlines of the perinuclear membranes were traced manually by using an A5 Wacom graphics tablet and segmented by a custom-written macro for the NIH Image 1.59 program (developed at the US National Institutes of Health and available from the Internet at http://www.rsb.info.nih.gov./ nih-image/). Distinct chromatin species were segmented by thresholding the nuclear area (Kittler and Illingworth 1986) into chromatin regions and their contour profiles (Marinelli et al. 1998). The reliability of the histogram-based grey- level thresholding approach had previously been assessed on nuclear regions of interest (ROIs) randomly selected from a single nucleus by using an NIH Image 1.61 release on a G4 Macintosh computer running MAC OS 9. Grey-level values established from ROI images that had been smooth-filtered and analysed by an SPSS 6.1 program were found to fit well into two Gauss distributions (Glasbey and Horgan 1995). The optimal grey-level threshold was set at the intersection point between these two distributions and then used to segment ROI images into two grey-level domains, namely one domain situated below the threshold and pertaining to the inter(eu)chromatin space and another domain above it and pertaining to the heterochromatin space. The grey-level threshold (average) established for nuclear ROIs was used to segment the whole nucleus of breast cancer cells, after interactive removal of nucleoli, which would have interfered with the estimation of the fractal dimension of the nuclear chromatins (Rigaut 1987).

\section{FD analysis}

The fractal parameters of the selected cell components were determined from digital micrographs by using the FANAL++ package (Dollinger et al. 1998). This includes subroutines for box-counting, data fitting and visualisation and the power law application procedure for setting the scaling window from which a straight line can be drawn, its slope being used to evaluate the FD (Losa and Nonnenmacher 1996). The box-counting method was applied to entire nuclei to determine the FD of grey-level
Fig. 3 Time-course expression of membrane (PI, Annexin- $V)$ and nuclear (TUNEL, Sub GO/ $G 1$ peak) apoptotic markers in SK-BR-3 cells, untreated $(U)$ and treated $(T)$ with $1 \mu \mathrm{M}$ calcimycin at $0 \mathrm{~h}$ (white columns), $24 \mathrm{~h}$ (grey columns) and $72 \mathrm{~h}$ (black columns). Results (\%) are means $\pm 1 \mathrm{SD}$ of three separate experiments. Parameter values $(72 \mathrm{~h})$ are significantly different at $P>0.001$

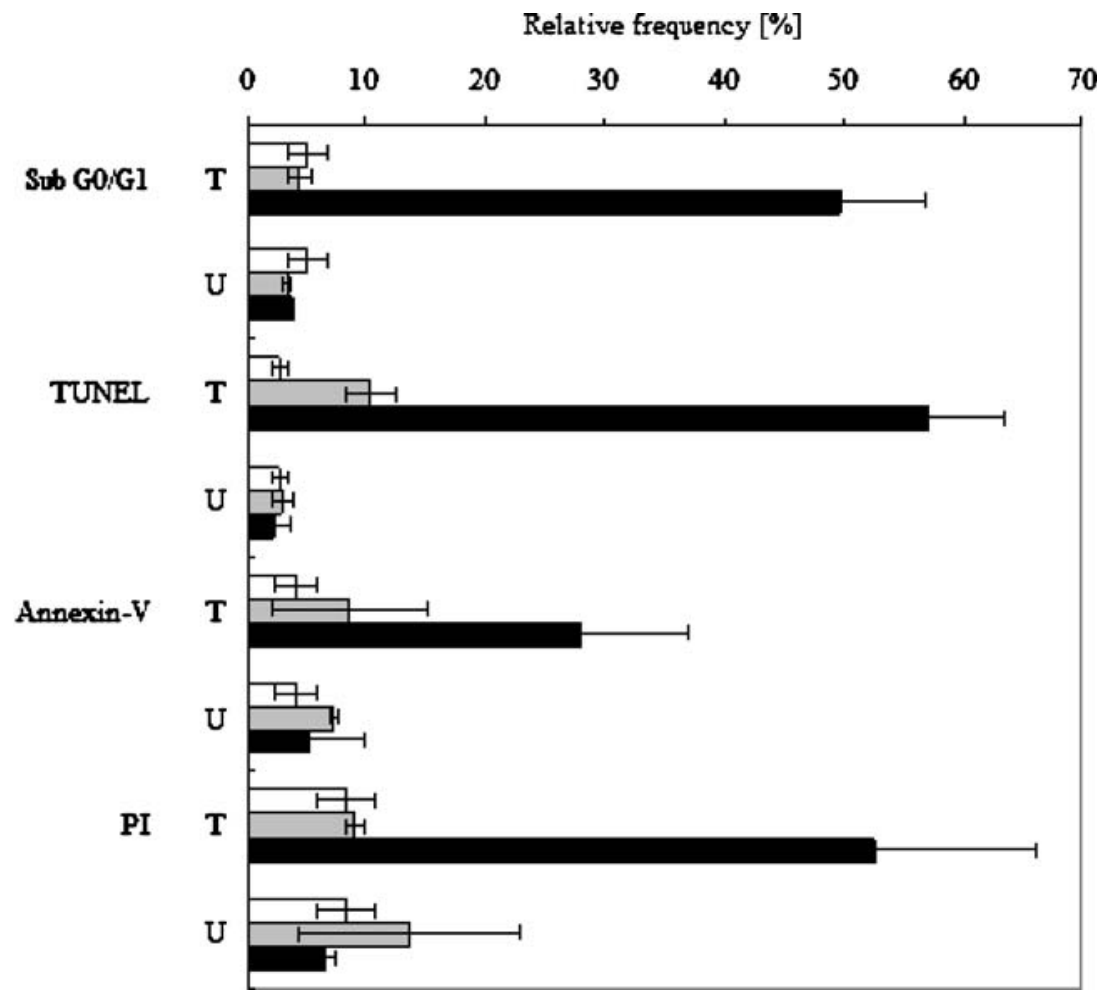


Table 1 Composition of gangliosides in SK-BR-3 cell lines evaluated by densitometric analysis

\begin{tabular}{|c|c|c|c|c|c|c|c|}
\hline \multicolumn{8}{|c|}{ SK-BR-3 cells } \\
\hline \multirow[b]{2}{*}{ Ganglioside } & \multirow[b]{2}{*}{$\mathrm{Rf}$} & \multicolumn{2}{|l|}{ Untreated } & \multicolumn{2}{|l|}{$24 \mathrm{~h}$} & \multicolumn{2}{|l|}{$96 \mathrm{~h}$} \\
\hline & & $\mu \mathrm{g} / \mathrm{spot}$ & $\mu \mathrm{g} / 10^{7}$ cells & $\mu \mathrm{g} / \mathrm{spot}$ & $\mu \mathrm{g} / 10^{7}$ cells & $\mu \mathrm{g} / \mathrm{spot}$ & $\mu \mathrm{g} / 10^{7}$ cells \\
\hline $\mathrm{X} 1$ & 0.272 & n.c. & n.c. & n.c. & n.c. & n.c. & n.c. \\
\hline $\mathrm{X} 2$ & 0.197 & - & - & - & - & n.c. & n.c. \\
\hline $\mathrm{GD}_{1 \mathrm{a}}$ & 0.046 & $0.123 \pm 0.004$ & $0.409 \pm 0.013$ & $0.076 \pm 0.005$ & $0.152 \pm 0.011$ & $0.583 \pm 0.028$ & $0.583 \pm 0.028$ \\
\hline $\mathrm{GT}_{1 \mathrm{~b}}$ & 0.009 & - & - & - & - & - & - \\
\hline $\mathrm{X} 4$ & 0.003 & n.c. & n.c. & n.c. & n.c. & n.c. & n.c. \\
\hline
\end{tabular}

SK-BR-3 cells were treated with $1 \mu \mathrm{M}$ calcimycin for 24 or $96 \mathrm{~h}$. Results are means \pm SD of three separate experiments $(R f$ retention factor of known gangliosides and unidentified sphingolipid spots, $X 1, X 2, X 3, X 4$ unidentified sphingolipid constituents, n.c. spot not evaluated because of unavailability of standard ganglioside, - undetectable spot)

threshold-segmented images of perinuclear membrane outlines and of intranuclear chromatin components, total heterochromatin (HC), nuclear-membrane-bound heterochromatin (NMBHC), scattered heterochromatin (SHC) and inter(eu)chromatin (IC). The FANAL++ program was run on a workstation equipped with Linux S.U.S.E 6.2. (Fig. 1; Dollinger et al. 1998; Baumann et al. 1994).

\section{GLCM analysis}

The GLCM represents second-order statistics (Haralick et al. 1973; Conners et al. 1984; Carstensen 1992) and has become one of the best known and most widely used texture features (Haralick et al. 1973). It is based on the repeated occurrence of certain grey-level configurations in the texture, which serves to estimate image textural features (Pican et al. 1998). The $\mathrm{G} \times \mathrm{G}$ GLCM $p_{d}$ for a displacement

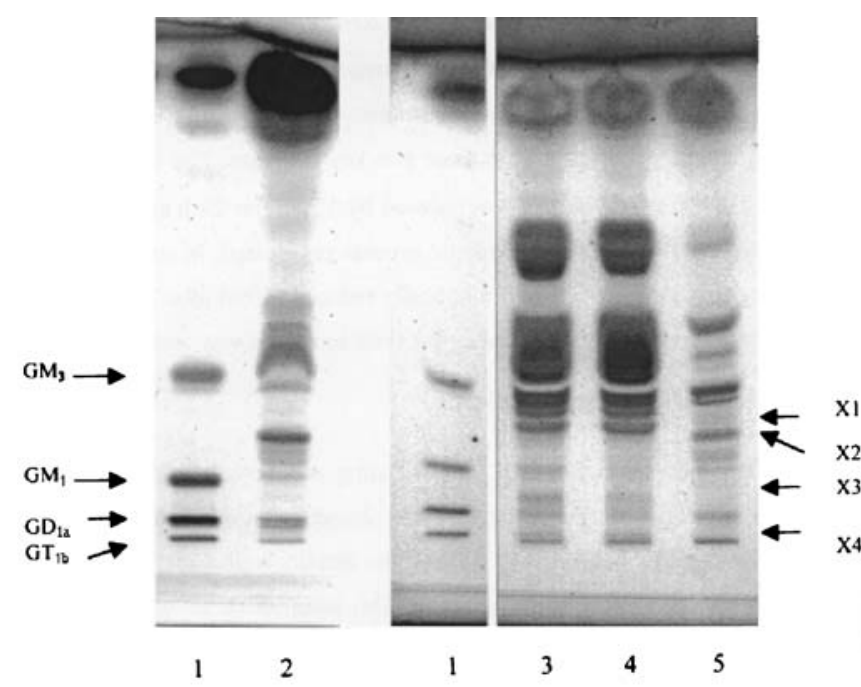

Fig. 4 HPTLC of gangliosides in MCF-7 and SK-BR-3 cells (lanes 1 standard gangliosides $\mathrm{GM}_{1}, \mathrm{GM}_{2}, \mathrm{GD}_{1 \mathrm{a}}$ and $\mathrm{GT}_{1 \mathrm{~b}}$, lane $2 \mathrm{MCF}-7$ cells, lane 3 untreated SKBR-3 cells, lane 4 1-day treatment with $1 \mu \mathrm{M}$ calcimycin, lane 54 -day treatment with $1 \mu \mathrm{M}$ calcimycin) vector $(d, \theta)$ is defined as follows: the entry $(i, j)$ of $p_{d}$ is the number of occurrences of the pair of grey levels $i$ and $j$ that lie a distance $(\mathrm{d}, \theta)$ apart (Tuceryan and Jain 1998). As the name suggests, the GLCM is constructed from the image by estimating the pair-wise statistics of pixel intensity. Each element $(i, j)$ of the matrix represents an estimate of the probability that two pixels with a specified separation have grey levels $i$ and $j$. The separation is usually specified by a displacement, $d$, and an angle, $\theta$. Thus, GLCM $\Phi$ $(\mathrm{d}, \theta)=[\mathrm{p}(i, j \mid \mathrm{d}, \theta)]$ and $\Phi(\mathrm{d}, \theta)$ will be a square matrix of side equal to the number of grey levels in the image and will usually not be symmetrical. The GLCM analysis includes statistical parameters such as angular second moment, contrast, correlation, variance, inverse difference moment, sum average, sum entropy, sum variance, entropy, difference variance, difference entropy, measure of correlation 1 and measure of correlation 2 (Haralick et al. 1973; Castelli 2001).

GLCM was applied to analyse the textural features of intranuclear ROIs, as defined above. All the above textural features were calculated with the pgmtexture routine in the netpbm graphic package (Castelli 2001). The average value of each parameter from the pooled four angles $\theta\left(\theta=0^{\circ}\right.$, $\left.45^{\circ}, 90^{\circ}, 135^{\circ}\right)$ was calculated at defined distances, $\mathrm{d}(\mathrm{d}=1$, $2,3,4,5,10,100)$.

\section{Statistics}

Data were analysed by a $t$-test and by the Mann-Whitney U-test (two-tail $P$ values) with SPSS 6.1 software.

\section{Results}

\section{Cellular parameters of apoptosis}

The progression of apoptosis from the initial $(24 \mathrm{~h}$ treatment) to active phases was followed in SK-BR-3 cells by measuring the behaviour of four different parameters in cells cultured for $96 \mathrm{~h}$ with $1 \mu \mathrm{M}$ calcimycin. No changes 
Fig. 5 FDs of various chromatin domains in control untreated cells (white columns, $n=14$ ) and SK-BR-3 cells treated with $1 \mu \mathrm{M}$ calcimycin for $24 \mathrm{~h}$ (light grey, $n=15)$ and $72 \mathrm{~h}$ (dark grey, $n=3$ ). The scaling window was defined within the range $\left[\varepsilon_{\min }-\varepsilon_{\max }=0.043 \mu \mathrm{m}-43 \mu \mathrm{m}\right]$; $\varepsilon=$ box side $(N M$ perinuclear membrane, $N M B H C$ nuclear membrane-bound heterochromatin space and outline, $S H C$ scattered heterochromatin space and outline, $H C$ total heterochromatin space and outline, IC inter(eu)chromatin space and outline). *Significance $0.01<P<0.05$ evaluated by Mann-Whitney test

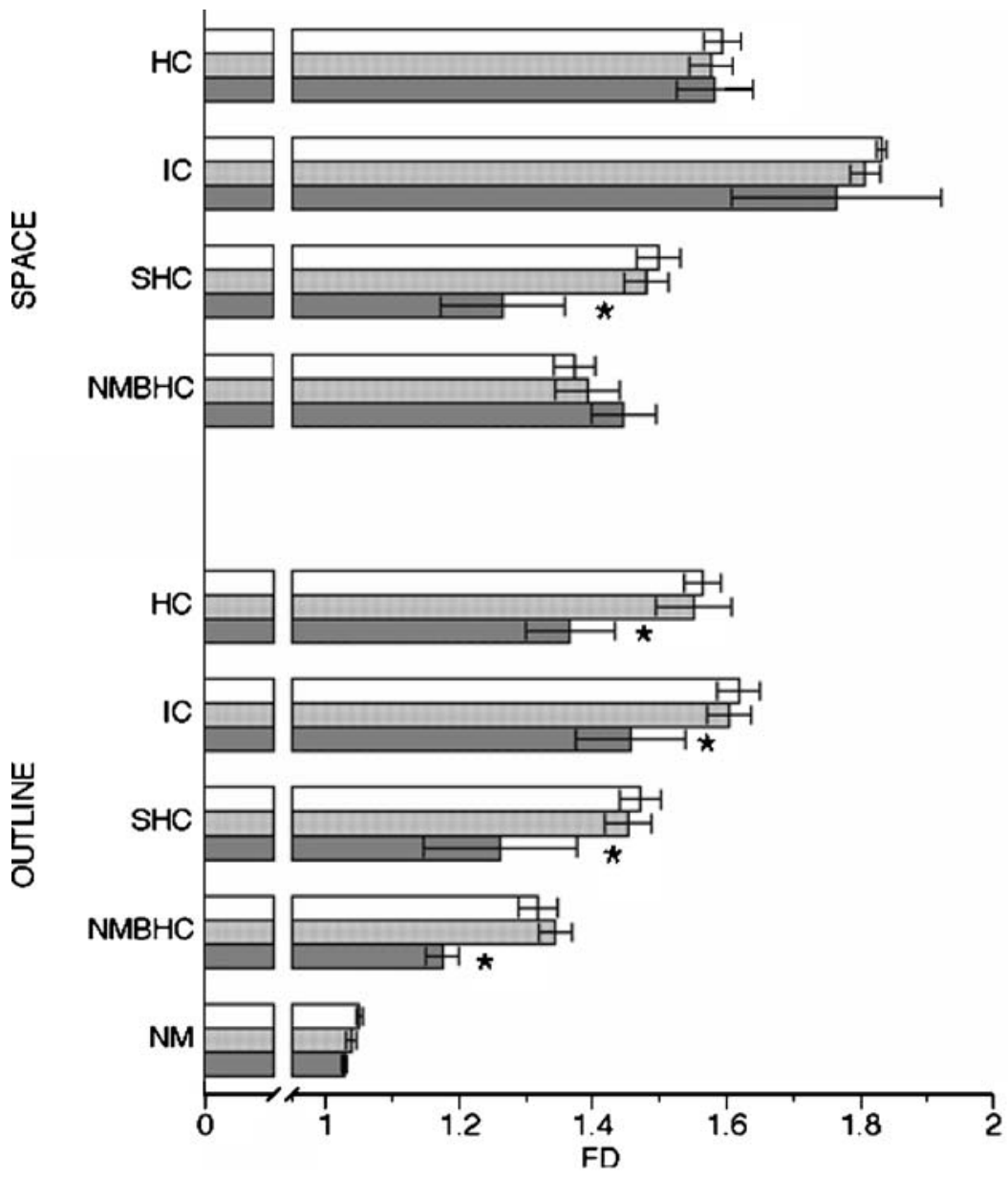

of these parameters were observed at $24 \mathrm{~h}$ of treatment (Fig. 3). Annexin-V-positive cells (28\%) occurred only after $72 \mathrm{~h}$ in culture, whereas cells with intermediate permeability to PI $(27 \%)$ and a sub $G_{0} / G_{1}$ peak $(15 \%)$ or TUNEL-positive $(23 \%)$ cells with DNA fragmentation (prone to apoptosis) were detected only after $48 \mathrm{~h}$ in culture. The number of cells expressing these cell markers increased significantly at $72 \mathrm{~h}$ of treatment (Fig. 3) and until the completion of apoptosis after $96 \mathrm{~h}$ (data not shown).

\section{Sphingolipid distribution}

The quantitative evaluation of HPTLC chromatograms revealed that glycosphingolipids of the mono-ganglio series were the most abundant in oestrogen-insensitive SK-BR-3 cells. The major component was $\mathrm{GM}_{3}$ followed by $\mathrm{GM}_{1}$ and the disialoganglioside $\mathrm{GD}_{1 \mathrm{a}}$, a composition similar to that of oestrogen-sensitive MCF-7 cells (Fig. 4). The $\mathrm{X} 1$ component from SK-BR-3 cells probably corresponded to $\mathrm{GM}_{2}$ ganglioside according to the $\mathrm{Rf}$ value established in MCF-7 cells, whereas $\mathrm{GT}_{1 \mathrm{~b}}$ was undetectable (Fig. 4, Table 1). SK-BR-3 cells treated with calcimycin for either $24 \mathrm{~h}$ or $96 \mathrm{~h}$ displayed ganglioside levels lower than those of untreated cells. Their content decreased with the progression of the apoptotic process, except for the disialoganglioside $\mathrm{GD}_{1 \mathrm{a}}$, which was expressed at a level close to that of viable cells (Table 1). The chromatograms indicated that $\mathrm{GM}_{1}$ and unidentified gangliosides $\mathrm{X}_{2}$ and $\mathrm{X}_{3}$ were not detectable in cells exposed to the ionophore for $24 \mathrm{~h}$. However, we noted the occurrence of $\mathrm{GM}_{1}$ and unidentified ganglioside $\mathrm{X}_{2}$ but not $\mathrm{X}_{3}$ in overtly apoptotic cells (Table 1 ). $\mathrm{X}_{2}, \mathrm{X}_{3}$ and $\mathrm{X}_{4}$ gangliosides could not be identified because of the lack of known standards.

Fractal analysis of ultrastructural features

Nuclei of SK-BR-3 cells exposed to calcimycin for $24 \mathrm{~h}$ and untreated SK-BR-3 cells (Fig. 1) had peculiar FD values of distinct components segmented by grey-level thresholding (Fig. 2), namely, $\mathrm{HC}=1.578 \pm 0.032$ vs. $1.595 \pm$ $0.029 ; \mathrm{IC}=1.808 \pm 0.023$ vs. $1.833 \pm 0.007 ; \mathrm{SCH}=1.482 \pm$ 0.033 vs. $1.499 \pm 0.033$; and $\mathrm{NMBHC}=1.393 \pm 0.049$ vs. $1.374 \pm 0.031$ (Fig. 5). FD values of the corresponding outline nuclear components were also generally reduced; however, no significant difference was found in the FD for any nuclear components in untreated cells and those treated for $24 \mathrm{~h}$ (Fig. 5). In contrast, significant changes occurred in most nuclear parameters, including marginalisation and condensation of chromatin, in overtly apoptotic cells $(72 \mathrm{~h}$ of treatment); these could be consistently detected on his- 
Table 2 GLCM parameters estimated as a function of the distance $(\mathrm{d}=1,2,3)$ on ROIs of untreated cells $(n=42)$ or ROIs of SK-BR-3 cells treated for $24 \mathrm{~h}$ with calcimycin $(n=44)$

\begin{tabular}{|c|c|c|c|c|c|c|c|}
\hline \multirow[t]{3}{*}{ GLCM parameters } & & \multicolumn{6}{|l|}{ Distance $(\mathrm{d})$} \\
\hline & & \multicolumn{2}{|l|}{$\mathrm{d}=1$} & \multicolumn{2}{|l|}{$\mathrm{d}=2$} & \multicolumn{2}{|l|}{$d=3$} \\
\hline & & Untreated & Treated & Untreated & Treated & Untreated & Treated \\
\hline \multirow[t]{3}{*}{$\begin{array}{l}\text { Angular second } \\
\text { moment }\end{array}$} & Range & $\begin{array}{l}0.000183- \\
0.00108\end{array}$ & $\begin{array}{c}0.00015- \\
0.0184\end{array}$ & $\begin{array}{c}0.000116- \\
0.00064\end{array}$ & $\begin{array}{l}0.0000985- \\
0.0104\end{array}$ & $\begin{array}{c}0.0000954- \\
0.000498\end{array}$ & $\begin{array}{l}0.0000821- \\
0.0065\end{array}$ \\
\hline & Mean & 0.0004 & 0.00111 & 0.00024 & 0.000673 & 0.00021 & 0.00047 \\
\hline & Median & 0.0003 & 0.00032 & 0.0002 & 0.0002015 & 0.000169 & 0.0001685 \\
\hline \multirow[t]{3}{*}{ Contrast } & Range & $42.2-393$ & $83.7-503$ & $120-1040$ & $236-1380$ & $201-1650$ & $402-2310$ \\
\hline & Mean & 208.5 & 249.5 & 561 & 695 & 857.3 & 1096 \\
\hline & Median & 199 & 200.5 & 547 & 554 & 853.5 & 873 \\
\hline \multirow[t]{3}{*}{ Correlation } & Range & $0.855-0.958$ & $0.869-0.964$ & $0.659-0.885$ & $0.659-0.900$ & $0.536-0.815$ & $0.513-0.834$ \\
\hline & Mean & $0.899 * *$ & $0.915 * *$ & $0.744 * *$ & $0.78 * *$ & $0.63 * *$ & $0.67 * *$ \\
\hline & Median & $0.895 * * *$ & $0.918 * * *$ & $0.742 * *$ & $0.783 * *$ & $0.623 * *$ & $0.673 * *$ \\
\hline \multirow[t]{3}{*}{ Variance } & Range & $322-2180$ & $517-3560$ & $319-2160$ & $513-3530$ & $317-2140$ & $511-3490$ \\
\hline & Mean & $1028 * * *$ & $1502 * * *$ & $1018 * * *$ & $1488 * * *$ & $1010 * * *$ & $1474 * * *$ \\
\hline & Median & $1090 * * *$ & $1385 * * *$ & $1080 * * *$ & $1370 * * *$ & $1070 * * *$ & $1355^{* * *}$ \\
\hline \multirow{3}{*}{$\begin{array}{l}\text { Inverse difference } \\
\text { moment }\end{array}$} & Range & $0.069-0.203$ & $0.065-0.188$ & $0.041-0.122$ & $0.038-0.133$ & $0.032-0.095$ & $0.029-0.104$ \\
\hline & Mean & 0.106 & 0.107 & 0.064 & 0.065 & 0.05 & 0.051 \\
\hline & Median & 0.095 & 0.103 & 0.058 & 0.061 & 0.046 & 0.047 \\
\hline \multirow[t]{3}{*}{ Sum average } & Range & $78.7-251$ & $95.5-297$ & $77.7-247$ & $94.4-293$ & $76.6-244$ & $93.4-290$ \\
\hline & Mean & $156.4^{*}$ & $175.9^{*}$ & $154.5^{*}$ & $173.9^{*}$ & $152.7^{*}$ & $171.9^{*}$ \\
\hline & Median & 161 & 166.5 & 159 & 164.6 & 157 & 162.5 \\
\hline \multirow[t]{3}{*}{ Sum entropy } & Range & $2.14-2.56$ & $2.23-2.6$ & $2.11-2.52$ & $2.19-2.56$ & $2.07-2.47$ & $2.15-2.54$ \\
\hline & Mean & $2.37 * *$ & $2.434 * *$ & $2.32 * *$ & $2.40 * *$ & $2.29 * *$ & $2.36^{* *}$ \\
\hline & Median & $2.39 * *$ & $2.43 * *$ & $2.36^{* *}$ & $2.39 * *$ & $2.31 * *$ & $2.35 * *$ \\
\hline \multirow[t]{3}{*}{ Sum variance } & Range & $7190-69800$ & $10900-96100$ & $7020-68100$ & $10600-93300$ & $6840-66500$ & $10400-91700$ \\
\hline & Mean & $29060 *$ & $37372 *$ & $28387^{*}$ & $36525^{*}$ & $27759 *$ & $35718^{*}$ \\
\hline & Median & $28750^{*}$ & $32050 *$ & $28150^{*}$ & $31250^{*}$ & $27550^{*}$ & $30550 *$ \\
\hline \multirow[t]{3}{*}{ Entropy } & Range & $3.12-3.9$ & $3.39-3.99$ & $3.29-4.01$ & $3.51-4.08$ & $3.35-4.02$ & $3.53-4.08$ \\
\hline & Mean & 3.61 & 3.66 & 3.74 & 3.79 & 3.76 & 3.81 \\
\hline & Median & 3.67 & 3.66 & 3.79 & 3.78 & 3.8 & 3.82 \\
\hline \multirow[t]{3}{*}{$\begin{array}{l}\text { Difference of } \\
\text { variance }\end{array}$} & Range & $\begin{array}{l}-1.12 \mathrm{e}-6-1.03 \mathrm{e}- \\
5\end{array}$ & $-1 e-6-2.96 e-6$ & $\begin{array}{l}-6.37 \mathrm{e}-7-6.03 \mathrm{e}- \\
6\end{array}$ & $\begin{array}{l}-5.85 e-7-6.48 \mathrm{e}- \\
6\end{array}$ & $-4.73 e-7-4.49 e-6$ & $-4.6 e-7-1.45 e-6$ \\
\hline & Mean & $1.83 e-6^{*}$ & $1.16 \mathrm{e}-6^{*}$ & $1.07 \mathrm{e}-6^{*}$ & $6.83 \mathrm{e}-7^{*}$ & $8.28 \mathrm{e}-7^{*}$ & $5.21 \mathrm{e}-7^{*}$ \\
\hline & Median & $1.31 \mathrm{e}-6$ & $1.14 \mathrm{e}-6$ & $7.68 \mathrm{e}-6$ & $6.48 \mathrm{e}-7$ & $5.97 \mathrm{e}-7$ & $4.87 \mathrm{e}-7$ \\
\hline \multirow{3}{*}{$\begin{array}{l}\text { Difference of entro- } \\
\text { py }\end{array}$} & Range & $1.14-1.61$ & $1.28-1.66$ & $1.35-1.81$ & $1.49-1.87$ & $1.45-1.89$ & $1.59-1.96$ \\
\hline & Mean & 1.44 & 1.48 & 1.65 & 1.69 & $1.73 * *$ & $1.78 * *$ \\
\hline & Median & 1.46 & 1.46 & 1.67 & 1.67 & 1.75 & 1.76 \\
\hline \multirow[t]{3}{*}{$\begin{array}{l}\text { Measure of } \\
\text { correlation } 1\end{array}$} & Range & $-0.297--0.183$ & $\begin{array}{l}-0.312- \\
-0.197\end{array}$ & $-0.215--0.107$ & $-0.221--0.115$ & $-0.181--0.085$ & $-0.177--0.087$ \\
\hline & Mean & $-0.224 * *$ & $-0.241 * *$ & $-0.143 * * *$ & $-0.163 * * *$ & $-0.115^{* * *}$ & $-0.134 * * *$ \\
\hline & Median & $-0.219 * * *$ & $-0.241 * * *$ & $-0.141 * * *$ & $-0.162 * * *$ & $-0.113 * * *$ & $-0.131 * * *$ \\
\hline \multirow{3}{*}{$\begin{array}{l}\text { Measure of } \\
\text { correlation } 2\end{array}$} & Range & $0.713-0.85$ & $0.721-0.845$ & $0.52-0.756$ & $0.531-0.735$ & $0.332-0.654$ & $0.348-0.648$ \\
\hline & Mean & $0.769 * * *$ & $0.793 * * *$ & $0.612 * * *$ & $0.656^{* * *}$ & $0.472 * * *$ & $0.534 * * *$ \\
\hline & Median & $0.77 * * *$ & $0.794 * * *$ & $0.608 * * *$ & $0.655^{* * *}$ & $0.469 * * *$ & $0.535 * * *$ \\
\hline
\end{tabular}

Mean and median values of GLCM parameters from treated and untreated cells were analysed by the Mann-Whitney U-test. The distance $\mathrm{d}$ is expressed in pixels ( $\mathrm{d}=1$ is one pixel; one pixel corresponds to $14.03 \mathrm{~nm})$

$* 0.05>P>0.01$

$* * 0.01>P>0.001$

$* * * P<0.001$

tograms. A significant reduction of FD could be estimated on both SHC space and outline, and on HC/IC and NMBHC outlines (Fig. 5). Incubation with the ionophore for less than $24 \mathrm{~h}$ caused no significant changes in the ultrastructure of cell membrane or nuclear components. 
Statistical analysis of grey-level textures by GLCM

The GLCM data for nuclear ROIs from treated $(24 \mathrm{~h})$ and untreated cells indicated that there was a significant difference in the median values of 6/13 statistical descriptors of textural features, namely correlation, sum of entropy, sum of variance, variance and measure of correlation 1 and 2 , when estimated as a function of nearest distances $d(d=1$, 2,3 ) from neighbour pixels to central pixel (Table 2), while gradually reducing at distance greater than $\mathrm{d}>3$, as previously reported (Castelli 2001). The median values of the other seven descriptors (entropy included) in the ROIs of cells treated for $24 \mathrm{~h}$ were similar to those of control cells, indicating that the nuclear chromatin was far from being in the homogeneous condensation state usually reached in late apoptosis. The mean values of all these parameters mostly diverged from median values but were less statistically significant, at least for the greater distances $\mathrm{d}>3$ (Castelli 2001).

\section{Discussion}

A morphometric strategy that combines fractal geometry and GLCM statistical analysis was developed in order to identify and characterise apoptosis induced by calcimycin in oestrogen-insensitive SK-BR-3 human breast cancer cells. This strategy was found to allow the measurement of changes of grey-level-tresholding segmented textural features (space and outline) of nuclear components, namely the inter(eu)chromatin, scattered heterochromatin and total heterochromatin, and the perinuclear membrane-bound heterochromatin. The reorganisation of cell components, including chromatin, began during early phases of apoptosis induced in vitro by a $\mathrm{Ca}^{2+}$ ionophore, well before the exposure of membrane phosphatidylserine (PS), the occurrence of membrane permeability to PI, DNA fragmentation (TUNEL and subdiploid $\mathrm{G}_{0} / \mathrm{G}_{1}$ peak), chromatin condensation (compactness) and marginalisation and the formation of apoptotic bodies (Vermes et al. 1995; Oberhammer et al. 1993; Pellicciari et al. 1996; Del Bino et al. 1999). Microarchitectural alterations of the uninvolved colonic mucosa, as determined by increased FD, has been reported to precede the expression of conventional biomarkers of apoptosis, such as caspase 3 and TUNEL (Roy et al. 2004). Dependent on the apoptotic inductive mechanism, morphological alterations occur before the exposure of PS during apoptosis of peripheral blood lymphocytes (Cornelissen et al. 2002). The loss of structural complexity of the nuclear domains is less pronounced in SK-BR3 cells exposed to the apoptogen for $24 \mathrm{~h}$ than in the overt active phases of the apoptotic process $(72 \mathrm{~h})$, as reflected by a significant reduction of all the FDs of these cells. This might be because the spatial reorganisation actually takes place in nuclear components at the beginning of apoptosis but is so subtle that it cannot be extracted from or revealed by the histograms based on the two grey-level domains. Furthermore, the ultrastructural change in nuclear components is imperceptible in terms of size, together with the fractal scaling process, which occurs within a limited scale interval in biological structures (Nonnenmacher et al. 1994; Landini and Rigaut 1997). However, evidence for the spatial-textural reorganisation of nuclear chromatin in the early apoptotic phases of SK-BR-3 cells is provided by the changes in six out of thirteen second-order statistics parameters estimated by GLCM analysis. These findings support the low FD data presented in a previous paper, in which fractal analysis alone was used to characterise early phases of apoptosis by quantifying ultrastructural changes of cellular membranes and nuclear components (Castelli and Losa 2001). The behaviour and the ultrastructural rearrangement of nuclear domains and ribonucleoprotein-containing structures have been documented during overt apoptosis of lymphoid cells by conventional morphological and morphometric approaches (Falcieri et al. 1994a, 1994b; Biggiogera et al. 1997; Stuppia et al. 1996). GLCM analysis and morphological data of nuclear chromatin are reflected in the changes of ganglioside composition occurring in both early and late phases of cell death. These findings are in line with those reported previously (Losa 1986) but are in partial disagreement with others (Spiegel and Merrill 1996; Nohara et al. 1998). They underline the possible involvement of sialosphingolipid molecules, such as $\mathrm{GM}_{3}$ and $\mathrm{GD}_{3}$, as signalling mediators and inducers of apoptosis (De Maria et al. 1997; Marquina et al. 1996; Nojiri et al. 1999). At first glance, the loss of membrane gangliosides and their altered expression, which is caused by the apoptotic process and might be attributable to reduced expression by a shedding mechanism and/or to altered metabolic pathways, are in agreement with the reduction of the ultrastructural complexity of the plasma membrane at the initial and late phases of apoptosis (Castelli and Losa 2001). Our finding of a loss of morphological traits in the nuclei of calcimycininduced apoptotic cells supports data reported by authors who have shown a significant reduction in the FD of intranuclear chromatin in lymphoid Jurkat cells, in which apoptosis had been induced with APO/Fas (Santoro et al. 2002).

The analytical approach adopted to elucidate apoptotic structures and pathways in epithelial cancer cells deserves further consideration. Whereas the determination of conventional cell parameters is not suitable for describing the early phases of apoptotic cell death, both fractal and mathematical/statistical approaches may help to quantify those morphological changes that occur in the initial phases of apoptosis. The FD is a quantitative descriptor that can be used alone to identify the chromatin organisation and the ultrastructural changes of distinct cell components. In contrast, the mathematical statistical approach requires a large number of parameters to do so.

The present study highlights the usefulness of the fractal strategy for measuring irregular shapes and changes in sizes or dimensions of nuclear components, during apoptosis not only in non-oestrogen sensitive SK-BR-3 breast cancer cells, but also in other tissues sharing different morphological traits and functional peculiarities (Losa et al. 1999; De Vico et al. 2005; Piantanelli et al. 2002; 
Bernard et al. 2001; Dioguardi and Grizzi 2002). It also emphasises the relevance of quantitative ultrastructural morphology for reassessing the morphological information used in the past to recognise apoptosis in cells and tissues.

Acknowledgements Helpful discussions with Prof. Theo Nonnenmacher, University of Ulm, Germany and Prof. Carlo Pellicciari, University of Pavia, Italy are gratefully acknowledged.

\section{References}

Baish JW, Jain RK (2000) Fractals and cancer. Cancer Res 60:36833688

Baumann G, Barth A, Nonnenmacher TF (1994) Measuring fractal dimension of cell contours: practical approaches and their limitations. In: Nonnenmacher TF, Losa GA, Merlini D, Weibel ER (eds) Fractals in biology and medicine, vol 1. Birkhäuser, Basel Boston Berlin, pp 182-189

Bernard F, Bossu JL, Gaillard S (2001) Identification of living oligodendrocyte developmental stages by fractal analysis of cell morphology. J Neurosci Res 65:439-445

Bianciardi G, Miracco C, Santi MD, Perrone A, Bruni A, Luzi P (2002) Fractal dimension of lymphocytic nuclear membrane in Mycosis fungoides and chronic dermatitis. In: Losa GA, Merlini D, Nonnenmacher TF, Weibel ER (eds) Fractals in biology and medicine, vol 3. Birkhäuser, Basel Boston Berlin pp 150-155

Biggiogera M, Bottone MG, Pellicciari C (1997) Nuclear ribonucleoprotein-containing structures undergo severe rearrangement during spontaneous thymocyte apoptosis. A morphological study by electron microscopy. Histochem Cell Biol 107:331336

Carstensen JM (1992) Description and simulation of visual texture. Institute of Mathematical Statistics and Operations Research, Technical University of Denmark, Lyngby, Denmark

Castelli C (2001) Apoptotic cell death in human breast cancer cells: characterisation of functional pathways and fractal-statistical image analysis of cellular ultrastructures. PhD Thesis. University of Lausanne, Lausanne, Switzerland

Castelli C, Losa GA (2001) Ultrastructural complexity of nuclear components during early apoptotic phases in breast cancer cells. Anal Cell Pathol 23:1-9

Chan KL (1995) Quantitative characterization of electron micrograph image using fractal feature. IEEE Trans Biomed Eng 42:1033-1037

Conners RW, Trivedi MM, Harlow CA (1984) Segmentation of a high-resolution urban scene. Comput Vis Graph Image Process 25:273-310

Cornelissen M, Philippé J, De Sitter S, De Ridder L (2002) Annexin $\mathrm{V}$ expression in apoptotic peripheral blood lymphocytes: an electron microscopic evaluation. Apoptosis 7:41-47

Cross SS (1994) The application of fractal geometric analysis to microscopic images. Micron 5:101-113

De Maria R, Lenti L, Malisan F, d'Agostino F, Tomassini B, Zeuner A, Rippo MR, Testi R (1997) Requirement for GD3 ganglioside in CD-95 and ceramide-induced apoptosis. Science 277:1652-1655

De Vico G, Peretti V, Losa GA (2005) Fractal organization of feline oocyte cytoplasm. Eur J Histochem 49(2):151-156

Del Bino G, Darzynkiewicz Z, Degraef C, Mosselmans R, Fokan D, Galand P (1999) Comparison of methods based on annexin-V binding, DNA content or TUNEL for evaluating cell death in HL-60 and adherent MCF-7 cells. Cell Prolif 32:25-37
Dioguardi N, Grizzi F (2002) Fractal dimension exponent for quantitative evaluation of liver extracellular matrix in biopsy specimens. In: Losa GA, Merlini D, Nonnenmacher TF, Weibel ER (eds) Fractals in biology and medicine, vol 3. Birkhäuser, Basel Boston Berlin, pp 113-120

Dollinger JW, Metzler R, Nonnenmacher TF (1998) Bi-asymptotic fractals: fractals between lower and upper bounds. J Phys Math Gen 31:3839-3847

Doudkine A, MacAulay C, Poulin N, Palcic B (1995) Nuclear texture measurements in image cytometry. Pathologica 87:286299

Einstein AJ, Wu HS, Sanchez M, Gil J (1998) Fractal characterization of chromatin appearance for diagnosis in breast cytology. J Pathol 185:366-381

Falcieri E, Gobbi P, Zamai L, Vitale M (1994a) Ultrastructural features of apoptosis. Scanning Microsc 8:653-666

Falcieri E, Zamai L, Santi S, Cinti C, Gobbi P, Bosco D, Cataldi A, Betts C, Vitale M (1994b) The behaviour of nuclear domains in the course of apoptosis. Histochemistry 102:221-231

Ferguson DJP, Anderson TJ (1981) Ultrastructural observation on cell death by apoptosis in the resting human breast. Virchows Arch 393:193-203

Glasbey CA, Horgan GW (1995) Image analysis for the biological Sciences. In: Barnett $\mathrm{V}$ (ed) Statistics in practice. Wiley, Chichester

Gorczyca W, Gong J, Darzynkiewicz Z (1993) Detection of DNA strand breaks in individual apoptotic cells by the in situ terminal deoxynucleotidyl transferase and nick translation assay. Cancer Res 53:1945-1951

Graber R, Losa GA (1995) Changes in the activities of signal transduction and transport membrane enzymes in CEM lymphoblastoid cells by glucocorticoid-induced apoptosis. Anal Cell Pathol 8:159-176

Gwag BJ, Canzoniero LM, Sensi SL, Demaro JA, Koh JY, Goldberg MP, Jacquin M, Choi DW (1999) Calcium ionophores can induce either apoptosis or necrosis in cultured cortical neurons. Neuroscience 90:1339-1348

Haralick RM, Shanmugam K, Dinstein IH (1973) Textural features for image classification. IEEE Trans Syst Man Cybern 69:610621

Irinopoulou T, Rigaut JP, Benson MC (1993) Toward objective prognostic grading of prostatic carcinoma using image analysis. Anal Quant Cytol Histol 15:341-414

Kerr JFR, Wyllie AH, Currie R (1972) Apoptosis: a basic biological phenomenon with wide-ranging implication in tissue kinetics. Br J Cancer 26:239-257

Kerr JFR, Winterforth CM, Harmon BV (1994) Apoptosis. It's significant in cancer and cancer therapy. Cancer 73:2013-2026

Kittler J, Illingworth J (1986) Minimum error thresholding. Pattern Recogn 19:41-47

Ladisch S, Gillard B (1985) A solvent partition method for microscale ganglioside purification. Anal Biochem 146:220 231

Landini G, Rigaut JP (1997) A method for estimating the dimension of asymptotic fractal sets. Bioimaging 5:50-70

Landini G, Rippin JW (1993) Fractal dimension of epithelialconnective tissue interfaces in premalignant and malignant epithelial lesions of the floor of the mouth. Anal Quant Cytol Histol 15:144-151

Landini G, Rippin JW (1996) Quantification of nuclear pleomorphism using asymptotic fractal model. Anal Quant Cytol Histol $18: 167-176$

Losa GA (1986) Plasma membrane properties in human breast tissues and cell lines. Ann N Y Acad Sci 464:431-435

Losa GA, Graber R (1998) Apoptotic cell death and the proliferative capacity of human breast cancer. Anal Cell Pathol 16:1-10

Losa GA, Nonnenmacher TF (1996) Self-similarity and fractal irregularity in pathologic tissues. Modern Pathol 9:174-182 
Losa GA, Baumann G, Nonnenmacher TF (1992) Fractal dimension of pericellular membranes in human lymphocytes and lymphoblastic leukemic cells. Pathol Res Pract 188:680-686

Losa GA, Graber R, Baumann G, Nonnenmacher TF (1999) Effects of steroid hormones on nuclear membrane and membranebound heterochromatin from breast cancer cells evaluated by fractal morphometry. Anal Quant Cytol Histol 21:430-436

MacAulay C, Palcic B (1990) Fractal texture features based on optical density surface area. Use in image analysis of cervical cells. Anal Quant Cytol Histol 12:394-398

Mandelbrot BB (1983) The fractal geometry of the nature. Freeman, San Francisco

Maraldi NM, Zini N, Santi S, Ognibene A, Rizzoli R, Mazzotti G, Manzoli FA (1998) Cytochemistry of the functional domains of the nucleus in normal and in pathologic conditions. Eur $\mathrm{J}$ Histochem 42:41-53

Marinelli F, Santoro R, Maraldi NM (1998) Fractal analysis of heterochromatin in nuclear domains in lymphocytes. In: Losa GA, Merlini D, Nonnenmacher TF, Weibel ER (eds) Fractals in biology and medicine, vol 2. Birkhäuser, Basel Boston Berlin, pp 220-225

Marquina G, Waki H, Fernandez LE, Kon K, Carr A, Valiente O, Perez R, Ando S (1996) Gangliosides expressed in human breast cancer. Cancer Res 56:5165-5171

Müthing J (1996) High resolution thin-layer chromatography of gangliosides. J Chromatogr A 720:3-25

Nicoletti I, Migliorati G, Pagliacci MC, Grignani F, Riccardi C (1991) A rapid and simple method for measuring thymocyte apoptosis by propidium iodide staining and flow cytometry. J Immunol Methods 139:271-279

Nielsen B, Albregtsen F, Danielsen HE (1999) The use of fractal features from the periphery of cell nuclei as a classification tool. Anal Cell Pathol 19:21-37

Nohara K, Wang F, Spiegel S (1998) Glycosphingolipid composition of MDA-MB-231 and MCF-7 human breast cancer cell lines. Breast Cancer Res Treat 48:149-157

Nojiri H, Manya H, Isono H, Yamana H, Nojima S (1999) Induction of terminal differentiation and apoptosis in human colonic carcinoma cells by brefeldin A, a drug affecting ganglioside biosynthesis. FEBS Lett 453:140-144

Nonnenmacher TF, Baumann G, Barth A, Losa GA (1994) Digital image analysis of self-similar cell profiles. J Biomed Comp 37:131-138

Oberhammer F, Fritsch G, Schmied M, Pavelka M, Printz D, Purchio T, Lassmann H, Schulte-Hermann R (1993) Condensation of the chromatin at the membrane of an apoptotic nucleus is not associated with activation of an endonuclease. J Cellular Sci 104:317-326

Ormerod MG, Collins MKL, Rodriguez-Tarduchy G, Robertson D (1992) Apoptosis in interleukin-3-dependent haemopoietic cells. J Immunol Methods 153:56-57

Paumgartner D, Losa GA, Weibel ER (1981) Resolution effect on the stereological estimation of surface and volume and its interpretation in terms of fractal dimensions. J Microsc 121:5163

Pellicciari C, Bottone MG, Schaack V, Barni S, Manfredi AA (1996) Spontaneous apoptosis of thymocytes is uncoupled with progression through the cell cycle. Exp Cell Res 229:370-377
Piantanelli A, Serresi S, Ricotti G, Rossolini G, Zaia A, Basso A, Piantanelli L (2002) Color based method for fractal dimension estimation of pigmented skin lesion contour. In: Losa GA, Merlini D, Nonnenmacher TF, Weibel ER (eds) Fractals in biology and medicine, vol 3. Birkhäuser, Basel Boston Berlin, pp $127-136$

Pican N, Trucco E, Ross M, Lane DM, Petillot Y, Ruiz IT (1998) Texture analysis for seabed classification: co-occurrence matrices versus self-organizing maps. IEEE Trans Biomed Eng $7: 424-428$

Raff M (1998) Cell suicide for beginners. Nature 396:119-122

Rigaut JP (1987) Natural objects show fractal grey tone functions: a novel approach to automated image segmentation, using mathematical morphology. Acta Stereol 6:799-810

Roy HK, Iversen P, Hart J, Liu Y, Koetsier L, Kim Y, Kunte DP, Madugula M, Backman V, Wali RK (2004) Down-regulation of SNAIL suppresses MIN mouse tumorigenesis: modulation of apoptosis, proliferation, and fractal dimension. Mol Cancer Ther 3:1159-1165

Santoro R, Marinelli F, Turchetti G, Zini N, Scotlandi K, Falcieri R, Maraldi NM (2002) Fractal analysis of chromatin during apoptosis. In: Losa GA, Merlini D, Nonnenmacher TF, Weibel ER (eds) Fractals in biology and medicine, vol 3. Birkhäuser, Basel Boston Berlin, pp 77-84

Savill JS (1997) Recognition and phagocytosis of cells undergoing apoptosis. Br Med Bull 53:491-508

Schwartzman RA, Cidlowski JA (1993) Apoptosis: the biochemistry and molecolar biology of programmed cell death. Endocr Rev $14: 133-151$

Sepulcre F, Grau J, Garcia-Bonafé M, Moragas A (1998) Fractal approach to the study of chromatin texture. In: Losa GA, Merlini D, Nonnenmacher TF, Weibel ER (eds) Fractals in biology and medicine, vol 2. Birkhäuser, Basel Boston Berlin, pp 226-230

Spiegel S, Merrill AHJ (1996) Sphingolipid metabolism and cell growth regulation. FASEB J 10:1388-1397

Squier MKT, Cohen JJ (1997) Calpain, an upstream regulator of thymocyte apoptosis. J Immunol 158:3690-3697

Stuppia L, Gobbi P, Zamai L, Vitale M, Falcieri E (1996) Morphometric and functional study of apoptotic cell chromatin. Cell Death Differ 3:397-405

Tuceryan M, Jain AK (1998) Texture analysis. In: Chen CH, Pau LF, Whang PSP (eds) The handbook of pattern recognition and computer vision. World Scientific Publishing, Singapore, pp 207-248

Vermes I, Haanen C, Steffens-Nakken H, Reutelingsperger C (1995) A novel assay for apoptosis. Flow cytometric detection of phosphatidylserine expression on early apoptotic cells using fluoroscein labelled annexin V. J Immunol Methods 184:39-51

Wagener R, Kobbe B, Stoffel W (1996) Quantification of gangliosides by microbore high performance liquid chromatography. J Lipid Res 37:1823-1829

Wehn B, Wouwer GVD, Koprowski M, Daele AV, Dhaene K, Scheunders P, Jakob W, Marck EV (1999) Value of morphometry, texture analysis, densitometry, and histometry in the differential diagnosis and prognosis of malignant mesothelioma. J Pathol 189:581-589

Wyllie AH, Kerr JFR, Currie AR (1980) Cell death: the significance of apoptosis. Int Rev Cyt 68:251-306 